\title{
PALESTINIAN UNIVERSITIES IN THE WEST BANK AND GAZA STRIP•
}

Especially since the outbreak of the Palestinian Intifädain December 1987, dispassionate analysis of the achievements, difficulties and relative intellectual seriousness of Arab institutions of higher learning in the Israeli-occupied West Bank and Gaza Strip has been in short supply. The closure of approximately fours years imposed by Israel early in 1988 resulted in much of Palestinian higher education being forced underground. Any discussion of Palestinian universities must attend to their political activities and their efforts at "nationbuilding" as well as to their academic standards and their effectiveness as higher educational institutions. ${ }^{1}$ To what extent do political commitments on the part of Palestinian teachers and students affect the quality of the academic experience offered by the universities?

\section{The Scale of Higher Education in the Occupied Territories}

At the beginning of the Intifäda there were six four-year institutions of higher education in the West Bank and Gaza Strip: Birzeit, Bethlehem, Hebron, An-Najah, Al Quds (Jerusalem), and Gaza Islamic universities. In 1992, Al Azhar University-Gaza was established as an institution administratively independent of Gaza Islamic University although sharing the same campus on land owned by Al Azhar in Cairo. ${ }^{2}$ Moreover, since 1991 a sort of open university has operated out of East Jerusalem which now provides distance-learning on a post secondary basis. With one minor exception, none of these insti-

- This is a revised and updated version of an article of the same title published in Minerva: $A$ Review of Science, Learning and Policy, XXIX, 3. Autumn 1991. pp. 249-268.

1 For the only published scholarly works which focus on these topics, see Sullivan, Antony T., Palestinian Universities Under Occupation, Cairo Papers in Social Science, XI, 2 (Cairo: American University in Cairo Press, 1988); and "Politics and Relevance in Palestinian Higher Education: The Case of Birzeit University," American-Arab Affairs XXVII (Winter 198-89), pp. 58-69. See also Franks, Lynne Rosengrant, Israel and the Occupied Territories: A Study of the Educational Systems of Israel and the Occupied Territories and a Guide to the Academic Placement of Students in Educstional Institutions in the United States (Washington, D.C.: United States Information Agency, 1987). For reasons which remain unclear this outstanding volume was withdrawn by its sponsor shortly after publication. It can be obtained only as an "out-of-print" book through University Microfilms International.

2 In fact, Al Azhar University-Gaza was established largely as a consequence of the resignation from Gaza Islamic University of some 16 faculty members as a result of tensions between Hamas and Fatah. As of early 1994, tensions between these two factions continued at Gaza Islamic University but were notably absent at Al Azhar University-Gaza. For this information I am indebted to Professor Charles E. Butterworth. personal communication. February 9, 1994. 
tutions has graduate students; An-Najah University in Nablus provides training for a master's degree in education. With the partial exception of Hebron University, all the Palestinian universities offer unidergraduates opportunities to specialize, i.e. "major," in the sciences and liberal arts. Birzeit, Bethlehem and An-Najah offer majors in economics and business administration, while Birzeit and An-Najah have degree courses in engineering for undergraduates. Training in nursing and in medical technology is available at Bethlehem and Al Quds universities. In their organization and programs of study most resemble American liberal arts colleges. Indeed they have been explicit in their acknowledgment that they took the American liberal arts college as their model. English has been the language of instruction in engineering and the sciences at all the Palestinian universities. In the humanities and social sciences Arabic has ordinarily been used, except in courses in English language and literature and selected courses in "cultural studies." Generally, Palestinian academics oppose total Arabization of the curriculum. ${ }^{3}$

All the Palestinian universities in the territory occupied by Israel in 1967 were established by Palestinians as four-year institutions between 1972 and 1978. None has ever received financial support from the Israeli government. In fact, each has been required to pay value-added and other taxes on materials and equipment from which Israeli universities are either exempt or receive compensatory subsidies. The Jordanian government levies no taxes on its institutions of higher education. Most Palestinian universities were secondary school priors to the 1970s or, in the case of Gaza Islamic University, offered instruction solely in theology and Islamic law. Tuition fees during the 1980 s varied from US $\$ 60$ to 760 for an academic session. The ratio of students to teachers was 14:1 and was second only to that of Saudi Arabia among the Arab countries. Student numbers ranged from approximately 3,000 at Gaza Islamic University to about 1,200 at Bethlehem University. At the time of their closure by the Israelis in early 1988, these six universities had a total of 14,000 students of whom approximately 60 per cent were male and 40 per cent female. By 1993, the number of Palestinian students enrolled in higher education had swelled to some 17,000. The percentage of the age category of Palestinians in the West Bank and Gaza Strip who are pursuing advanced training continues to be greater than that of the inhabitants of any Arab country.

Students were admitted to Palestinian universities primarily on the basis of their performance on the Tawjihi, which is an obligatory examination for Palestinian high-school graduates aspiring to university education anywhere

\footnotetext{
3 On the question of Arabization, see Aghabekian, Varsen, "Perception of Effectiveness Indicators for the Development of an Instrument for Evaluating Colleges and Universities on the Occupied West Bank," unpublished dissertation, University of Pittsburgh, 1986, esp. pp. 142-143.
} 
in the Arab world. The Tawjih $j$ is administered or validated by Israel and Jordan in most of the West Bank, the same having been done by Israel and Egypt in Gaza until the Israeli withdrawal in 1994. The examination questions are now prepared and the examinations graded by Palestinians. In addition to those studying at universities, there were by 1993 more than 8,500 students attending 21 two year colleges in the Occupied Territories. None of those junior colleges is included in the present analysis.

Prior to 1967 and Israel's occupation, Palestinians encountered few obstacles either to leaving or returning to the West Bank and Gaza Strip. Before 1967 they commonly studied at universities in Syria, Lebanon and Egypt, as well as in Europe and the United States. As a result of their freedom of movement and the relatively easy access they enjoyed to Arab and foreign universities, there was little demand by Palestinians for a system of higher education in the West Bank or Gaza Strip. Certainly, neither Jordan nor Egypt made any effort to encourage such interest, fearful as they were of Palestinian separatist sentiment in the territory which they had incorporated or begun to administer after 1948. With the Israeli occupation in 1967, freedom of movement for Palestinians was significantly reduced, at least for those wishing to return to the conquered lands at the conclusion of their studies. Absences for longer than a year endangered the validity of the identity cards issued to Palestinians by the Israeli authorities Palestinians who wished to reside in the Occupied Territories once they had completed their studies had to bear the expense of frequent return visits. Furthermore, after the $1967 \mathrm{War}, \mathrm{Pal}-$ estinians gradually became less welcome elsewhere in the Middle East, especially in Egypt, Jordan and Lebanon. These and other Arab countries feared that a distinctive Palestinian nationalism-especially in its terroristic incarnation-posed a challenge which might result in their social and political destabilization. Such developments, together with the growing number of Palestinians who had earned advanced degrees and who were willing to return and teach under Israeli rule, rendered feasible the establishment of indigenous institutions of higher learning.

What Palestinian educators have accomplished under Israeli occupation during the past quarter century has been achieved largely through their own efforts and against great obstacles. Nevertheless, without the aid of patrons, foreign and Palestinian, they could not have accomplished what they have. Substantial financial support from the Persian Gulf and from Islamic sources, much of it allocated to individual universities by the Palestinian Council of Higher Education located near Ramallah on the West Bank, combined with contributions from Palestinian individuals and organizations throughout the world, have contributed greatly to the existence of the universities and have enabled them to keep tuition fees low. Compared to higher education elsewhere in the Middle East and in the West, Palestinian universities have been inex- 
pensive. However, this situation is unlikely to continue, at least to the same degree. Because of the enormous financial losses which have resulted from the Intifäda and especially the Gulf War, all universities are now in the process of raising their tuition, which historically has covered only some 20 per cent of their operating expenses. In 1993 the Palestinian Council of Higher Education mandated a 50 per cent increase in tuition for all students. Birzeit University has gone beyond the 50 per cent mandate, having doubled its tuition for entering students. The financial condition of the universities nevertheless remains extremely fragile, aggravated as it is by the fall in oil prices and the fact that none has any endowment.

The truth is that Israel did permit Palestinians to establish universities and, despite closure during the Intifäda and the designation of "illegal" teaching as punishable by ten years in jail, did not announce the dissolution of any of the universities. During the 1970s, some Israelis might have believed that access to Palestinian universities would offer Palestinian youth an alternative to membership in the Palestine Liberation Organization. Other Israelis may have thought that the existence of opportunities to study in Palestinian institutions of higher learning would render advanced training in the Soviet Union less attractive to Palestinians. Israeli concern about study in the Soviet Union focused mainly on poorer Palestinians who could not afford the cost of higher education in the West. Although precise figures are unavailable, the number of Palestinians from the West Bank and Gaza Strip who in fact studied in the Soviet Union during the past quarter century has certainly been less than the number which studied in Western Europe and the United States. Frequently, young Palestinians studied both in the Soviet Union and in Western Europe or America: the equivalent of an MA might be earned in the Soviet Union and $\mathrm{a} \mathrm{PhD}$ in the United States-the opposite seldom occurred.

Perhaps most importantly, the existence of Palestinian universities provided Israeli intelligence agencies with a means to monitor ideological orientations and political trends within the Palestinian population. Both Israelis and Palestinians agree that Palestinian universities were rife with informers who provided the Israelis with important information. The barometer offered by the universities was especially useful during the 1980s, given the lack of other vehicles for Palestinian self-expression. It is also possible that the Israelis tolerated Palestinian institutions of higher education as a way of holding in check resentment among inhabitants of the Occupied Territories. ${ }^{4}$

4 These observations are based on the author's conversations between 1986 and 1990 with knowledgeable Israelis and Palestinians. 


\section{The Universities, the Israelis and the Palestinians}

From the outset, Palestinian universities have been subjects of intense controversy. Many Israelis have insisted that their real purpose is political propaganda and indoctrination, and have said that they observe low academic standards. Palestinians have maintained that their universities are committed to undergraduate education of good quality. Both sides agree that Palestinian universities have received financial support from the Palestine Liberation Organization, and that the Israeli occupation has burdened them with special difficulties. ${ }^{5}$

Israelis such as Major Elise Shazar, spokeswoman for the West Bank's civil administration, regard the Palestinian institutions of higher education in the Occupied Territories "not so much as universities, but as 'institutions of political activity', part of the infrastructure of the Palestine Liberation Organization. ${ }^{\text {"6 }}$ Indeed, Major Shazar has argued that Palestinian universities have been "central to PLO activity" 7 and have constituted the principal outlet for an anti-Israeli campaign guided by the Palestine Liberation Organization. According to Likud party leader Benjamin Netanyahu, the Palestine Liberation Organization has "mounted an all-out effort to subvert the academic purpose of the universities and turn them into centers of incitement, extremism and terror. ${ }^{8}$ A year before the outbreak of the Intifäda, a leader of the Tehiya party and former president of Tel Aviv University, Yuval Ne'eman, urged that all Palestinian universities be closed. ${ }^{9}$ In early 1990, the consulate general of Israel in New York charged that Palestinian universities have proven "academic institutions in name only," and have operated as bases for subversion against Israel. The consulate accused the universities of playing a "leading role in the instigation of violence and subversion [sic] activity since the beginning of the uprising in December 1987."10 In fact, Bethlehem University was closed before the Intifädabegan and other universities were shut within two months of its outbreak.

On these and related issues, Palestinians see matters differently. For Palestinians, the Israeli occupation is omnipresent. The moment one "faces a soldier, is searched, [or] applies for a travel permit," the Palestinian journalist

5 See (no author indicated) Lessons of Occupation: Palestinian Migher Education During the Uprising (Jerusalem: Jerusalem Media and Communication Centre, 1990.) This 36-page booklet is replete with statistics; it is the best short introduction to Palestinian higher education.

6 Wilkes, Curtis, "Universities Are Subject of Discord on West Bank," Baston Globe, 26 April, 1985.

7 Clines, Francis X., "Israelis Holding a U.S. Professor," The New York Times, 26 February, 1987.

- See Netanyahu's statement to the United Nations Security Council, 5 December, 1986, p. 2. This speech has been published by the Israeli Ministry of Foreign Affairs.

9 See Wilkie, Curtis, "Outcry Follows Israeli Army Gunfire," Bosion Globe, 15 December, 1986.

10 Policy Background (February 1990), p. 2. 
Daoud Kuttāb has written, "one comes face to face with politics. № matter how apolitical you are, you are forced into having political thoughts, ideas and preferences... The average Palestinian living under occupation questions everything, debates, agrees, disagrees-it does not matter. Each becomes aware of what is happening." ${ }^{11}$ The response to the success of a Palestinian surgeon, Dr. Shawqi Harb of Ramallah Hospital, in performing the first open heart operation in the Occupied Territories, shows how politics extends even to the most apparently non-political matters. In praise of Dr. Harb, an editorial in a leading Palestinian newspaper observed that this operation showed "a breed of Palestinian devoid of the victim mentality. Palestinians do not seek sympathy for [their] miseries from the world. [They] actively demand their rights and waste no effort in fighting for these demands. In this regard, the success of the medical operation is equal in importance to a diplomatic, political or military victory." 12

Given the pervasiveness of politics, it is hardly surprising that Palestinians look to their institutions of higher learning to assist them to withstand Israeli policy. Despite their emphasis on the development of human talent, it is simply not possible for Palestinian universities in the West Bank and Gaza Strip to disregard the political environment in which they operate. "It is impossible to conceive of a Palestinian university," the Jerusalem Post has observed, "that would not, to some degree at least, provide cover for the practice of Palestinian nationalist politics." 13 At Palestinian universities, like universities elsewhere, education touches on politics, especially in the social sciences and humanities. This does not necessarily entail the renunciation of academic standards in teaching and research in favor of propaganda. The question to consider is whether political partisanship has prevented free and rational debate and inquiry, diverted teachers from scholarly and scientific research, and deprived students of instruction of respectable quality.

Palestinian teachers are emphatic in rejecting suggestions that they have used their classrooms as platforms from which to propagandize the young. "We are not propagandists in our classrooms," Bernard Sabella at Bethlehem University has insisted: "Many of us have placed special emphasis on objectivity, particularly when we have discussed Israel and the Israeli occupation. Education is a process of growing up, and one cannot do that if one denies a part of the reality of the world in which one lives. ${ }^{\text {"14 }}$ Professor Sabella observes that neither faculty nor students object to the study of books by Jewish or Israeli scholars on Israeli, Palestinian or Arab topics. At Birzeit University, widely perceived by Israelis as the most partisan among Palestinian universi-

11 See Kuttab, Daoud, "After the Honeymoon." Nerv Outl(k)k (August 1986), pp. 11-12.

12 AJ.Fajr (English edition), 30 January, 1987.

13 See editorial, "Extremists in Embrace," Jerusalem Post, 5 March, 1985.

14 Sabella to the author, 6 August, 1986. 
ties on behalf of the Palestine Liberation Organization, Mr. Samīr Șbehāt, a president of the student council, stated publicly in 1987 that he would "accept a [political] solution that did not require a separate nation but only the extension of full human rights by the Israelis." 15

In early 1988, shortly after the eruption of the Intifäda, Albert Aghazarian, the director of public relations at Birzeit University, emphasized that Palestinian universities simply could not allow themselves to politicize education. ${ }^{16}$ In his opinion, each Palestinian university "embraces a community of [different] political currents and opinions. The duty of [a] university administration is to allow the maximum freedom of discussion... while ensuring that the civil liberties of each member of the university community are preserved and that academic standards are maintained and developed in a responsible fashion. ${ }^{17}$ Indeed, much of what may appear as impassioned political activity seems to many instructors to relate rather to such pragmatic issues as academic salaries, the grading of examinations, and requirements for degrees. ${ }^{18} \mathrm{My}$ own observation of Palestinian classes and the governing bodies at Palestinian universities over several years confirms the view of the Israeli scholar, Mattityahu Peled, that Birzeit and other Palestinian universities have always aspired to be primarily traditional institutions of higher learning. ${ }^{19}$

\section{Restrictions on Academic Freedom and Academic Standards}

Since 1980, preoccupation with politics in Palestinian universities has been exacerbated by Israeli policy. Israeli restrictions on academic freedom have contributed to the intensity of the political discussion which is prominent in Palestinian universities. This has made their maintenance of solid academic standards more difficult. Examples of these restrictions are Israeli Military Order 854, issued on 5 July, 1980, Israeli application in the Gaza Strip in 1983 and 1985 of Egyptian government Order 380, and the "permit" to operate a "private educational institution" in the West Bank issued by the Israeli civil administration on 28 June, 1990. Military Order 854 was an amendment of Jordanian Law No. 16 which applied to elementary and secondary schools in the West Bank only. Military Order 854 substituted the "Officer in the Israeli

\footnotetext{
15 Quoted in Clines, F.X., "Israelis Hdding a U.S. Professor," op. cit.

16 See al-Ghazali, Said, "Closure of Universities Seen as Never-Ending," A/ Fajr (English edition), 15 January, 1990.

17 See Aghazarian, A., letter, Jerusa/em Post, 11 March, 1985

18 For a detailed discussion of political conflict within Palestinian universities, see Sullivan, A.T., Palestinjan Unjversities, op. cit., passim.

19 See Peled, Mattityahu, "Intifada Interlude," Nerr Outlook, July 1990, p. 43. Br Peled's summary of the conflicting pressures to which Birzeit University in particular has been subjected, see pp. 43-44.
} 
Army in Charge of Education" for the Jordanian Ministry of Education, and invested the Israeli military with authority over Palestinian universities in the Occupied Territories.

Military Order 854 gave the Israeli authorities broad powers over all Palestinian universities, including the right to license them annually, control their courses of study and syllabuses, admit their students, and approve and dismiss their instructors. On the basis of Military Order 854, Israel demanded that all "foreign" members of the teaching staff sign a statement, in conjunction with their application for a work permit, denying affiliation with any organization "hostile" to Israel. Specifically, such instructors were required to deny membership in the Palestine Liberation Organization. Most members of the teaching staff refused to sign, stating that they were being obliged to espouse a particular political attitude. As a result, the Israeli military began deportations of such teachers, whose ranks included native Palestinians to whom the Israelis have denied residential status. In autumn 1982, 18 teachers of An-Najah University, including the president of the university, Dr. Munther Șalāh, were expelled, as were three professors from Birzeit and one from Bethlehem. Several dozen lecturers were forbidden to teach.

The result was widespread criticism of Military Order 854 in Israel and throughout the world. Two hundred Israelis signed a letter of protest against the measure; it was also criticized by the United States Secretary of State, George Shultz. In 1981, an ad hoc committee of Israeli teachers at Hebrew University criticized Military Order 854 as constituting an "infringement of academic freedom." It added that the order was "not a suitable legal framework for regulating the universities [since] it applies rules which were not meant for universities and are not suitable for them. The supervision required on security grounds can be exercised (as it has been in the past) without resort to Order 854 . $^{20}$ Perhaps as a result of these protests, the Israeli military announced in November 1982 that Military Order 854 was to be suspended. A year later, the statement concerning political affiliation was eliminated from applications for work permits. However, Military Order 854 has not been rescinded.

Similar in effect to Military Order 854 has been Israeli application of Egyptian Order 380. Adducing Order 380. Israel in 1983 required teachers at the Islamic University of Gaza to obtain work permits from the military governor. Six teachers were immediately refused permission to teach. In August 1985. Israel demanded that the university accede to three conditions for the grant or renewal of work permits. These were: acknowledgment of Order 380 which, as amended, would authorize Israeli supervision of university affairs; dissolution of the nursing program which had been established at the

20 Quoted from Gerner, Deborah J., "Israeli Restrictions on the Palestinian Universities in the Occupied West Bank and Gaza," Journal of Arab Alfairs, VIII, 1 (1989), pp. 95-96. 
university in the previous year; and acceptance of supervision of the university's finances by Israel. When the Islamic University refused to accept these conditions, 34 of its teachers were denied renewal of their work permits and were obliged to leave the Occupied Territories. ${ }^{21}$

The effect of these measures in the West Bank and Gaza Strip has been the opposite of what the Israelis seem to have intended. Universities increasingly have come to be regarded by Palestinians-as they apparently already were by Israelis-as agents of political conflict. Palestinians have been made more aware of the ease with with their intellectual leaders can be suppressed. Political activity, which has always been present in Palestinian higher education, has been intensified by Israeli attempts to control and censor teaching and publication.

In 1990, Israel indicated a determination to revive Military Order 854. On 28 June, 1990, the Israeli authorities conveyed to an-Najah National Intermediate Community College in the West Bank city of Nablus a document which is based explicitly on "UJordanian] Law No. 16. . क amended by the Israeli Military Order No. 854 of the year 1980." This document, in Arabic, is entitled "Permit to Operate a Private Educational Institution for the Academic Year 1989-1990." It is signed by Dr. Fawāz Kamāl, officer for educational affairs of the civil administration for Judea and Samaria. An-Najah Community College is one of the two-year, post-secondary institutions which the Israelis permitted to reopen during the first half of 1990 . The terms of this new document have reimposed Military Order 854 in a more sophisticated fashion. The document asserts:

The institution's administration is responsible for the institution's students, its teachers, and its employees in terms of preventing the following acts from occurring, both within the institution and in its vicinity:

Disturbing public order, participating in marches or demonstrations without prior permission on the part of the competent authorities;

Holding meetings and exhibitions of a political nature without prior permission on the part of the competent authorities;

Preparing, printing and distributing any publication forbidden by the censorship and any other publication aimed at inciting or disturbing public order;

Any violation of the Military Order concerning incitement and hostile propaganda (Judea and Samaria) number 101 of the year 5727-1967.

21 For information on Military Orders 854 and 380, see Lessons of Occupation. Palestinian Higher Education During the Uprising, op. cit., esp. pp. 14-16. 
The statement continues:

The institution's administration will not hire any teachers, lecturers or other employees who do not live in Judea and Samaria unless they have been granted a work permit and appropriate documents under the law and security provisions;

The administration of the institution commits itself not to admit students from outside the area of Judea and Samaria unless they have been given permission to live and study in the area by the commander of the area;

The administration commits itself to present to the officer in charge of education all pertinent information regarding the following points: a. Financial reports on income and expenditure of all types; $b$. Sources of funding of the institution and purposes of expenditure; c. A list of teachers, employees and students including all personal details; d. Any additional information which may from time to time be requested by the civil administration;

The administration of the institution, by virtue of the granting of this license, takes upon itself to comply with all of the contents of Military Order 854 concerning education... ;

Prior permission must be obtained for the addition of any subject or an increase in the number of classes, students and teachers;

Nothing contained in the conditions accompanying this permit may be construed to reduce any of the obligations incumbent upon the institution, its employees, its lecturers and its students under the law and the requirements for the maintenance of order;

The violation of any of the conditions contained in this permit justifies its revocation without any prior warning.

Clearly, this démarche by the Israeli military has sought to assert comprehensive political control over An-Najah Community College, and has imposed on that institution political responsibilities which its administration, given the situation which exists in the Occupied Territories, cannot fulfill. Nevertheless, since the universities were allowed to reopen Israel has largely refrained from direct interference in the operation of Palestinian higher education. Most of the bureaucratic mechanisms to do so remain in place, however, should Israel ever decide on a change in policy.

\section{Academic Quality}

The level of academic attainment by instructors at the Palestinian universities is not very different from that of professors at many middle-range American liberal arts colleges (Table I). 


\section{Table I}

\section{Degrees Held by Full-time Teachers}

at Palestinian Universities, 1984-1980

\begin{tabular}{|c|c|c|c|}
\hline Institution & $\begin{array}{l}\text { Full-time } \\
\text { Teachers }\end{array}$ & $\begin{array}{c}\text { Recipients of } \\
\text { Doctorate }\end{array}$ & Masters \\
\hline Birzeit & 206 & 97 & 79 \\
\hline Bethlehem & 90 & 28 & 46 \\
\hline An-Najah & 197 & 92 & 72 \\
\hline Hebron ${ }^{b}$ & 50 & 18 & 28 \\
\hline Al Qudsc & 146 & 37 & 54 \\
\hline Gaza Islamic & 162 & 33 & 47 \\
\hline
\end{tabular}

- All data are for the academic session 1985-86, with the exception of Gaza Islamic University, the data for which apply to the academic session 1984-85.

b A paucity of data on Hebron University precludes discussion of that institution.

c Al Quds University consists of four different institutions, so statistics concerning it should be used with caution. Al Quds Arab Women's College, a liberal arts institution, had 14 teachers, of whom five held a PhD.

SOURCES: Data were compiled from Aghabekian, V., "Perception of Effectiveness Indicators," op. cit, p. 20; Franks, L.R.. Israef and the Occupied Territories, op.cit, p. 246.

Many PhDs, especially at Birzeit, Bethlehem and An-Najah universities, received their advanced training in Western Europe or North America. For example, teachers appointed by Birzeit University in 1986 included PhDs from Paris X, Nanterre, the University of Lille, the University of Iowa, and Emory University. Even at the Islamic University of Gaza, the staff in 1986 was sprinkled with holders of PhDs from such Western institutions as the University of London, the University of Stuttgart, the University of Kansas and Washington State University. It is clearly the case that all Palestinian universities during the past 15 years have had teaching staffs which received advanced academic training at universities of reasonable intellectual standards.

As liberal arts institutions, Palestinian universities have understood their mission as primarily that of teaching and service to their community, rather than research and scholarly publication. In this they are not too different from traditional American liberal arts colleges and the agricultural and mechanical colleges which flourished before the Second World War. Nevertheless, scholarly research has been accomplished by individual teachers at some Palestinian universities, usually with little financial support.

In this respect, Birzeit University clearly leads. In 1988-89, instructors at Birzeit published at least 25 scholarly articles in professional journals or 
in the proceedings of scholarly conferences. By April 1990, another 30 had been published. ${ }^{22}$ During 1992 and 1993, at least 11 additional articles appeared. ${ }^{23}$ These papers were included in journals or monographs published throughout the world. For teachers in engineering and the sciences, European and American publications were especially well represented. At least eight books written or edited by instructors at, or formerly at, Birzeit University were published in English or Arabic between 1988 and 1990. Examples include Mahmoud Ibrahim's Merchant Capital and Islam, and Sharif Kanaana and Ibrahim Muhawi's Speak Bird, Speak Again: Palestinian Arab Folktales. ${ }^{24}$ A book by Ziad Abu Amr, Islamic Fundamentalism in the West Bank and Gaza, was published in $1994 .{ }^{25}$ All of this has been achieved despite an environment highly unfavorable to serious scholarship.

Research has not been the only indication of intellectual vigor at Birzeit University. The university publishes its own professional journal, Birzeit Research Review-recently renamed Afäg Filistiniyyz-which considers contributions from all disciplines. The Center for Environmental Health and Occupational Safety at Birzeit has monitored the quality of local water and that of pharmaceutical drugs in circulation on the West Bank. The university's parasitology laboratory has focused especially on parasitic infestation in schoolage children. In 1993, a Law Center was in the process of formation.

Particularly suggestive of the intellectual vitality of Birzeit are two international conferences organized by its faculty and held on its campus during the summer of 1993. The first, a symposium of mathematicians, featured presentations by President Ivar Ekeland of the University of Paris and Vice-President of the American Mathematical Society Chandler David, and Professors Mary Gray (American University), John Milnor (SUNY at Stony Brook) and Melvin Rothenberg (University of Chicago). This conference constituted the first major activity of the recently established Palestinian Society for Mathematical Sciences. The second conference addressed the topic, "Palestine, the Arab World and the Emerging International System: Values, Culture and Politics," and included presentations by both scholars and men of affairs. Among those making plenary addresses or reading papers were the Right Honorable Lord Ian Gilmour, a British parliamentarian, and Professors Ibrahim Abu Lughod (Birzeit University), J.P. Chagnollaud (University of Paris), Michael Hudson (Georgetown University) and Ghada Karmi (University of London).

There is much less research and publication at An-Najah University. The University does maintain a research and documentation center which con-

22 See Birzeit University Nervsletter, March 1989, pp. 7-8; ibid. April 1990, pp. 8-11.

23 Kbid, September 1993, p. 15.

24 Published respectively by the University of Texas Press in 1990 and the University of California Press in 1989.

25 Bloomington: Indiana University Press. 
tains important primary materials on Palestinian history. It also conducts a translation program to make scholarly works in Hebrew and English on Palestinian and Arab history available in Arabic. The library of the center possesses at least 213 American doctoral dissertations dealing with Islam and the Arab world. An-Najah University also publishes a journal, the Journal of Research, which considers submissions from all fields. When An-Najah teachers do publish, it is usually in this journal.

Neither Gaza Islamic University nor Al Azhar University-Gaza has any significant number of productive scholars. The unusually harsh conditions which prevail in the Gaza Strip do not permit much attention to research. Since the mid 1980s, Gaza Islamic University has operated a modest program to preserve Palestinian history and traditions, and has occasionally published its own professional journal, the Islamic University Research Review. Early in 1994, one Western scholar who visited both institutions observed that the faculty of each, although not actively involved in scholarship, was nevertheless "deeply committed to learning and to teaching." At Al Azhar UniversityGaza in particular, instructors impressed him as "highly innovative" in their teaching methods. He added: "There is little jockeying for power or grandstanding. Instead, one senses a deep bond of collegiality along with a common feeling that [professors] must work together to bring students along-a communal feeling surely enhanced by the awareness of surrounding forces which wish [everyone] ill. 26

Interestingly, several members of the faculty at Al Azhar UniversityGaza are actively involved in teaching in a new Arabic Great Books program now operating in both Gaza City and Khan Younis. Organized in its current form by Professor Charles E. Butterworth of the University of Maryland, the Continuing Education and Extension Program for Adults and Teachers (CEEPAT) offers instruction in Arabic in the classics of the Islamic tradition utilizing techniques of critical reading pioneered by the late Professor Leo Strauss and currently employed at such American institutions as St. John's College. The program is designed especially for secondary school teachers and hopes soon to confer an MA degree in Liberal Studies. As of early 1994, three semesters of instruction had been offered by professors from Al Azhar University-Gaza trained by Professor Butterworth in techniques of discussion designed to encourage student participation and discourage learning by rote. Al Azhar University-Gaza recently agreed in principle to offer the MA to CEEPAT students who complete 10 courses for a total of 30 credits, as did Bethlehem University on the West Bank. CEEPAT has benefited from grants from the Fulbright-Hayes program as well as from the United States Infor-

${ }^{26}$ Professor Charles E. Butterworth to the author, personal communication. February 9, 1994. 
mation Service and the American-Mideast Educational and Training Services (AMIDEAST).

Bethlehem University was established by the de la Salle Brothers under the auspices of the Vatican with the objective of serving Palestinian society in a way which would discourage the emigration of young Arabs from the West Bank. Therefore, it has traditionally emphasized application of the expertise of its teaching staff to the practical problems of Palestinian society. While the university has such individual scholars as the sociologist Bernard Sabella and the political scientist Manwil Hassassian, who have good reputations in both the Arab world and the West, its focus is on vocational training and social service. It permits students to specialize in nursing and hotel management, and has attempted to establish a course of study to train Palestinians as tourist guides. Major conferences have been organised on the teaching of English as a foreign language, and on ecological trends in the Levant. Of all Palestinian universities, Bethlehem University perhaps has the clearest understanding of precisely what its objectives are, and what activities might best realize those objectives.

\section{Teaching}

In the opinion of Professor Emile Sahliyeh, a political scientist formerly at Birzeit University who currently teaches at North Texas State University in the United States, the performance of students at Birzeit University has been "at least as good" as that which he now finds at North Texas State. Professor Sahliyeh observes that since he teaches the same courses, uses many of the same books and administers the same examinations at North Texas State University as he did at Birzeit, his views should be taken seriously. He says that students at Birzeit University "rarely cut classes and were eager to work and learn."27 The late Professor 'Izzat I. Ghūrani, a senior economist at Birzeit University, concurred. Professor Ghūrani believed that there were fewer poor students at Birzeit than he encountered as a visiting professor at the University of Texas at Austin in 1986, and that Birzeit's best students are comparable to those at Austin. ${ }^{28}$ My own observation of classes at Birzeit and other Palestinian universities suggests that the judgments of Professors Sahliyeh and Ghürani are accurate, and might be applied with little modification to the rest of the Palestinian institutions of higher learning in the West Bank.

Especially instructive in this regard is the Arab Women's College, a predominantly Muslim liberal arts institution with a full-time teaching staff of

27 Professor Sahliyeh to the author, 23 March, 1987.

28 Professor Ghürani to the author, 18 August, 1987. He observed, however, that Birzeit students need to learn to write papers of moderate length, free of flowery language, and that they should improve their ability to conduct independent research. 
14 and a student body of approximately 250. Perhaps because of its location in East Jerusalem, annexed by Israel in 1967 and governed by the provisions of Israeli law, the Arab Women's College has never been closed by Israel. It did close voluntarily between December 1987 and May 1988 to demonstrate sympathy with the Intifäda. Students at the Arab Women's College dress in conservative Muslim style, although almost none wear the veil.

In the summer of 1990, I observed one class in English and comparative literature taught by Professor Sumaya Talhami, who received her doctorate from the University of Illinois in Urbana in 1980. The visit was not announced in advance and I had not previously met her. This is one of the 27 courses in English literature or composition on the college course list and taught by Professor Talhami or others, although not all during the same academic year. Poetry discussed in this course included Auden's "Unknown Citizen," Blake's "London," Keat's "To Autumn," Shelley's "Ozymandias," and Thomas's "Adlestrop." Among the short stories or essays studied by students were works by Hemingway, Orwell, Saki and Camus. On the day of my visit the subject of discussion was Camus, and in particular his short story, The Guest.

Professor Talhami taught her 18 students in Socratic fashion. She placed special emphasis on problems of the conflict of civilizations, with particular reference to France and Algeria. Among the topics covered were levels of loneliness; the nature of compassion; whether essence is prior or subsequent to existence; and the concepts of otherness and alienation. Professor Talhami emphasized that for Camus, the "other" was necessary for the completion of the self, for the realization of the individual's own humanity. Sartre, existentialism, and secular values were each touched upon.

In this class as in others elsewhere in the West Bank, students do not hold back from participation in discussions in the classroom. Students regularly interrupted each other to reply to Professor Talhami, or to argue with her interpretation of the material or that of their colleagues. Clearly, the topics with which Camus grappled were very interesting to these young Palestinians, and were seen as relevant to the challenges they confront in their daily lives. A number of the Palestinian students in Professor Talhami's class have been politically active, and at least one has spent several years in an Israeli prison. It may well be that political commitment, and the price which many Palestinians students have paid for their political activism, have served to augment, rather than to diminish, the intellectual seriousness of Palestinian universities.

\section{The Achievements of Palestinian Graduates in American Universities}

The competence of at least the best Palestinian students from the West Bank and Gaza Strip and the quality of the undergraduate instruction which they received there can be assessed by the performance of Palestinians in American higher education. AMIDEAST has gathered data showing the ex- 
periences of Palestinian students to whom it has granted financial support to study in the United States. Beginning in 1978, it has selected such students from nominations submitted by the various Palestinian universities. Almost all the nominees have been teachers at the Palestinian institutions which proposed them, and a majority have received all or much of their undergraduate education at one or another of the Palestinian universities in the Occupied Territories. ${ }^{29}$ A total of 357 Palestinian teachers received AMIDEAST fellowships between 1978 and 1990; 294 successfully completed their programs, earning either a doctorate or a master's degree; 27 withdrew without completing the work for the degree which they had intended to earn (Table II).

\section{Table II}

\section{Achievements of Palestinian Recipients of Fellowships} from American-Mideast Educational and Training Services

$\begin{array}{lccccc} & \text { AMIDEAST } & \text { Completed } & \text { Degrees in } \\ \text { Institution } & \text { nominees } & \begin{array}{c}\text { degrees } \\ \text { progress }\end{array} & \begin{array}{c}\text { without } \\ \text { degree }\end{array} & \begin{array}{c}\text { GPA } \\ \text { (4.0) } \\ \text { average }\end{array} \\ \text { Bethlehem } & 41 & 34 & 6 & 1 & 3.69 \\ \text { Birzeit } & 97 & 89 & 1 & 7 & 3.64 \\ \text { An-Najah } & 85 & 75 & 5 & 5 & 3.52 \\ \text { Gaza Islamic } & 27 & 12 & 11 & 4 & 3.35 \\ \text { Total } & 250 & 210 & 23 & 17 & 3.55\end{array}$

- Gaza Islamic University entered the program only in 1985.

SOURCE: Records of AMIDEAST complied by Diana Kamal and her colleagues.

Twelve Bethlehem fellows earned advanced degrees in education, five in mathematics, and three in library science from such institutions as Catholic University, New York University, Pennsylvania State University and Syracuse University. Twelve grantees from Birzeit University completed degrees in engineering, 12 in language and literature, seven in mathematics, and seven in physics at such universities as Stanford, Michigan, Cornell and the University of Colorado at Boulder. The record of fellows from An-Najah University shows that 18 earned degrees in engineering, eight in business adminis-

29 According to Miss Sarah Gentry, former director of AMIDEAST's office in Jerusalem, a "clear majority" of recipients of AMIDEAST scholarships have had at least two years of undergraduate study at Palestinian universities in the Territories; in recent years most of the Palestinians selected have done all four years of their undergraduate studies at Palestinian universities in the West Bank or Gaza Strip. Since these universities were established only during the 1970s, and the AMIDBAST program began in 1978, it is obvious that a substantial number of AMIDEAST scholars studied as undergraduates at universities outside the Occupied Territories. It is not possible from existing records to separate those educated in the West Bank and Gaza from those trained elsewhere in the Arab World. 
tration, and nine in mathematics. The American universities which granted these degrees include Stanford, Southern Illinois University at Carbondale and the University of North Carolina at Chapel Hill. Three grantees from Gaza Islamic University have earned degrees in education, two in business administration, and two in physics from Southern Illinois University at Carbondale, Western Illinois University and the University of Arizona. AMIDEAST's best estimate is that only about half of the total of 27 instructors from all Palestinian universities who failed to complete their degrees did so for mainly academic reasons. This constitutes approximately 4 per cent of the total number of fellows sponsored by AMIDEAST and is a very low rate of failure.

\section{University Libraries}

The holdings of Palestinian university libraries are not extensive if compared with those of most American liberal arts colleges. However, their collections are heavily used by both sudents and faculty. ${ }^{30}$ The library at Gaza Islamic University is inferior to those of universities on the West Bank, both in holdings and in equipment. Library acquisitions throughout the Occupied Territories have been restricted by the Israeli authorities, especially as far as materials in Arabic are concerned.

The number of books in Palestinian university libraries ranges from approximately 90,000 at Birzeit University to 55,000 at An-Najah University, 25,000 at Bethlehem University, to perhaps 10,000 at Gaza Islamic University. A new library with the most modern equipment was completed at Birzeit University in 1985. That library accommodates 500 students and includes conference rooms, audio-visual and microfilm sections, and a rare book room. In 1993 the Birzeit library subscribed to 590 periodicals in English and 200 in Arabic. The libraries of Bethlehem and An-Najah universities have less than modern technology but contain sufficient space for users to work in relative comfort. At Bethlehem University, the library subscribes to 336 English and Arabic-language periodicals, while An-Najah subscribes only to a handful. The library at Gaza Islamic University has almost no periodicals, mechanical equipment is largely non-existent or broken-when I visited the library in August 1986, the only xerox machine had been broken for two monthsand a shortage of books has necessitated a two-day limit on borrowing. ${ }^{31}$

Palestinian university libraries possess many books by Western scholars and by Israeli and Jewish scholars. At Birzeit University, one finds prominently in evidence John Lewis Burckhardt's Travels in Arabja, H.R.B

\footnotetext{
30 This statement is based on personal observation and my interviews with university librarians

31 Closure of the universities and the collapse of outside financial support after the Gulf War have brought library acquisitions at all Palestinian universities almost to a standstill. Except for occasional minor donations, none of the libraries has added new books since the late $1980 \mathrm{~s}$. Birzeit has subscribed to only three new periodicals in the past six years, and the situation is worse elsewhere.
} 
Dickson's The Arab of the Desert, Charles M. Doughty's Travels in Arabia Deserta, and H. St. J.B Philby's Arabia of the Wahabis. Nearby are Marie Syrkin's Golda Meir: Woman with a Cause, Martin Lowenthal's edition of The Diaries of Theodor Herzl, The Jews in Their Land, edited by David BenGurion, Abba Eban's My People: The Story of the Jews, and Robert Silverberg's If I Forget Thee, O Jerusalem. At Bethlehem University, Edmund Wilson's The Scrolls from the Dead Sea, Jacques Berque's The Arabs. Their History and Future, and William H. McNeill's The Rise of the West are to be found not far from Edward Luttwak's The Israeli Army, Yigal Allon's Shield of David: The Story of Israel's Armed Forces, Teddy Kollek and Moshe Pearlman's Jerusalem, Sacred City of Mankind: A History of Forty Centuries, and Cecil Roth's A Short History of the Jewish People. The library of AnNajah University contains Eric Voegelin's The New Science of Politics, History of Political Philosophy, edited by Leo Strauss and Joseph Cropsey, Gustav von Grünebaum's Unity and Variety in Muslim Civilization, along with Misha Louvish's The Challenge of Israel, The Jews. Their Role in Civilization, edited by Louis Finkelstein, Mordechai Nisan's Israel and the Territories: A Study in Control, 1967-1977, and Palestinian Impasse: Arab Guerrillas and International Terror, edited by Lester A. Sobel. Finally, at Gaza Islamic University one observes novels by Jane Austen, Charles Dickens, Henry Fielding and Thomas Hardy not far from Moshe Dayan's Story of my Life, Howard Sachar's A History of Israel, and Robert Seltzer's Jewish People, Jewish Thought.

In the Occupied Territories, every book not officially approved by the Israelis for import or purchase is illegal. Since gaining such approval at best involves surmounting considerable bureaucratic obstruction and inefficiency, Palestinian universities have not obtained Israeli permission for a significant portion of their holdings. Frequently, the Israelis have ignored this fact. Palestinian university libraries have long been in violation of Israeli military law and may be closed whenever the Israelis desire. In 1985, there were approximately 350 titles on Israel's list of books specifically banned. This list included Vasilii V. Bartold's Studies in the History of Palestine in the Middle Ages, Rosemary Sayegh's The Palestinians: From Peasants to Revolutionaries, Ishaq Husseini's The Arabism of Jerusalem, Omar Abu-Risheh's Collected Poetry, and 'Alī Mạ̣mūd Țāha's Complete Poetical Works ${ }^{32}$ Any book focusing on Palestine as an historical, cultural or political concept, or expressing Arab nationalism or the idea of Arab unity, has been a certain candidate for exclusion from the Territories. Even an Arabic translation of a book on the Gush Emunim movement by Israeli journalist Danny Rubenstein has been

${ }^{32}$ See Sheni, Yitzhak, Chief Censor, Rules and Regulations Issued by the Judea and Samaria District, No. 71, Israeli Defense Forces, 26 April, 1985. This brochure describes itself as "An order concerning the banning of hostile propaganda activities," and is based on "The Defense Laws (State of Emergency), 1945." Entries are in Hebrew and Arabic. 
banned from the West Bank and Gaza Strip. Apparently, the Israeli government has long been determined to do what it can to eliminate any book which is somehow considered a threat to its national security, whomever it is written by. For Palestinian universities, a particularly detrimental aspect of this policy is that since the 1970s it has discouraged acquisition of important Arabiclanguage scholarly journals.

\section{Some Assessments of Palestinian Universities}

During the 1980s, Israeli and American academics evaluated Palestinian universities on different occasions. In 1981, five professors of the Hebrew University of Jerusalem wrote what has become known as the GavisonYaari report. The authors of the report were Professor Ruth Gavison and David Kretchmer of the faculty of law, Yehoshua Kolodny of the department of geology, Eliezar Rabinovitch of the department of physics and Menahem Yaari of the department of economics. ${ }^{33}$ Do Palestinian universities, these Israeli investigators asked, "maintain regular studies and/or research and do they aim to grant their students orderly and up-to-date education?" Their answer was affirmative: "Academic activity is conducted according to accepted norms and the [university] administrations strive for the advancement and regular maintenance of this activity." The Israelis reported that Palestinian university administrators were making "great efforts to assure the regular execution of [the] curriculum." They said that Palestinian institutions were characterized by a "large number of students who are interested in acquiring a higher education, and a large number of lecturers who are concerned with providing that education." The Israelis stressed that they had "no doubt that this is so. ${ }^{34}$

At the same time, the Israeli investigators gave attention to the charge that instruction at Palestinian universities "perverts reality and has little regard for the truth." Specifically, they examined the allegation that in "teaching geography of the Land of Israel maps are used on which Israeli settlements do not appear." The Israelis noted that at Birzeit University maps "published by the Survey Department of the State of Israel are used and the course in geography of the Land of Israel includes a tour which lasts a number of days and covers many Israeli sites." There was no doubt, they stated, that the course included "discussion of Israeli settlements which were erected in places on which previously Arab settlements stood." They observed, however, that the settlement issue could legitimately be analyzed in various ways. In con-

\footnotetext{
33 See their "Report on the Condition of Universities in the Occupied Territories," first published in American-Arab Affirs, XVI (Spring 1986), pp. 158-172.

34. Bbid., p. 160 .
} 
clusion, they reported "no evidence that the study of geography at Birzeit University is based on denying facts. ${ }^{* 35}$

In 1983, a committee appointed by the American Association of Catholic Colleges and Universities conducted an evaluation of Bethlehem University. Its final report strongly endorsed the academic integrity and relevance of courses at Bethlehem University, noting the unusual difficulties under which Bethlehem and the other Palestinian universities were laboring. ${ }^{36}$ The Catholic investigators were "favorably impressed by the unanimity among faculty and administration" as to the fundamental goals of the university:

An academic education is upheld by all. Career preparation. .. is also a clear goal .... The courses required in cultural subjects do not impinge to any great degree on the professional programs, and, in fact, provide a solid foundation for them.... A solid undergraduate education, adapted to the career possibilities for the Palestinians in that area, is the chosen way of serving the needs of the local community. There is a strong concept of service to such students and little or no pretension to be a more prestigious type of university. ${ }^{37}$

The investigators found a number of other strengths at Bethlehem University, stressing the priority given to "good academic standards" and the emphasis placed on "increasing [classroom] participation" by students, and on "analytic and creative thinking." The team expressed itself as "deeply impressed by the strength and commitment of the administration and faculty of the University. ${ }^{38}$

Deficiencies which the American evaluators described included a lack of computers and scientific equipment, a dearth of "special faculty training," and insufficient variety in teaching methods. The committee stated that "The weaknesses of the University are more difficult to identify (than the strengths] with any certitude." Library resources at Bethlehem University were "inadequate," especially given an "inability to develop inter-library loans to any significant degree. 39 Indeed, the committee emphasized that improvement of the library was a major need, and that the acquisition of such items as Biological Abstracts and Chemical Abstracts was "fundamental to

35 Ibid, pp. 160-161. The members of the committee were: Alice Gallin, OSU, executive director of the American Association of Catholic Colleges and Universities; Catherine McNamee, CSJ, president of the College of St. Catherine; Patrick Ellis, FSC, president of La Salle College; Mr. Robert Gale, president of the Association of Governing Boards; Rev. William McInnes, SJ. president of the Association of Jesuit Colleges and Universities; Joel Read. SSSF, president of Alverno College; Jean Wilkowski, chairman of the board of directors of Volunteers in Technical Assistance; and Dr. Robert Gordon, vice-president for advanced studies, University of Notre Dame.

${ }^{36}$ See Association of Catholic Colleges and Universities, Report on Bethlehem University, 20 January, 1984.

37 Ibid., p. 4.

38 Jbid., pp. 4-5, 9.

39 Jbid, pp. 5, 9. 
continued [professional] growth of the faculty and to the education of the brightest students. ${ }^{40}$ In conclusion, the American evaluators observed that "with moderation and patience Bethlehem University is trying to fulfill its obligations as a university, and to contribute to the quest of Palestinian society to exercise its basic rights to education, peace and justice. ${ }^{41}$ This assessment constituted an endorsement of the academic seriousness of Bethlehem University, and is applicable in most respects to other Palestinian universities as well. ${ }^{42}$

\section{Conclusion}

For Palestinians under occupation, higher education has been a serious business. Palestinians have traditionally regarded education as the one investment which cannot be confiscated. They have done what they could to assure that university instruction of respectable quality has been available to the younger generation in the West Bank and Gaza Strip. There is no doubt that Palestinian universities have been a vehicle for Palestinian political activities, support of the Palestine Liberation Organization, and endorsement of an independent Palestinian state. Palestinian universities have been obliged to assume some aspects of a national authority, given the dearth of other institutions in the Occupied Territories in which such authority might be vested. For example, members of their administrations and many of their teachers have for years been recognized by Palestinians as among their most important representatives in negotiations with Israeli officials and foreign dignitaries. Political activity on campus seems frequently to have stimulated, rather than compromised, Palestinian academic attainment, and to have helped both teachers and students to avoid intellectual apathy. Tensions between scholarship and politics have been present, but to date have not undermined the commitments of Palestinian universities to higher learning. If ever the Israeli occupation is terminated and the present financial crisis of the universities is solved, there is no reason not to expect Palestinian higher education to continue competently to fulfill its academic mission.

Center for Middle Eastern and North African Studies

ANTONY T. SULLIVAN

University of Michigan

Ann Arbor, Michigan

4o Jbid, Appendix B, p. 3.

4 Ibid., p. 8.

42 For application to Palestinian universities of accreditation criteria of the American North Central Association which confirm these judgments, see Sullivan. A.T, Palestinian Universities, op. cit, pp. 71-75. 